\title{
Legal Review Of Implementation Endowments Authority Relating To The Under Hand Agreement Made By Waqif (Case Study In Kua Wonosalam, Demak)
}

\begin{abstract}
Dewi Farhati ${ }^{1}$ and Ahmad Khisni ${ }^{2}$
Abstract. Waqf is a legal act of Waqif to separate and or hand over part of their wealth to be exploited forever or for a specified period. Usefulness of waqfitself for purposes of worship or public welfare according to the Shari'a. The purpose of the endowment given to nadzir of Waqif is to utilize waqf property in accordance with its function. The method used is a method socio-juridical with descriptive analytical research specifications, while the data analysis method used is qualitative analysis. Based on the results of research and discussion can be concluded that the power of the waqf agreement under the hand can be executed as long as their witnesses from several parties. During the relevant parties agree to the provision of the giiving waqf endowments by Waqif to nadzir have a valid legal provisions. Legally positive endowments implementation should be done with a pledge made before the Endowment Agreement Official Pledge (PPAIW) with two witnesses and should be made in the form of an agreement of Pledge of Endowments pursuant to Article 17 of Act No. 41 of 2004 on waqf. 1. Endowments statement implemented by Waqif to nadzir before PPAIW to be implemented by two witness; 2 . Endowments statement referred to in paragraph (1) shall be declared orally and / or in writing and set forth in the agreement of pledge endowments by PPAIW.

Keywords: Waqf, Endowments Authority, Under Hand Agreement.
\end{abstract}

\section{Introduction}

Indonesia consists of various tribes, customs and religion, and belief in God Almighty who is the potential for the presence of legal diversity. Indonesia has a legal system that is a compound that includes the applicable legal system has various shades and the composition itself, the system of customary law, Islamic law system, western legal systems (civil law).

For the people of Indonesia that the majority of people of Islamic religion, the waqf is one of worship that have a social dimension in the religious dimension Islam. It is not just solely a relationship to God (hablun min Allah, a vertical relationship), but also the relationship amongst humans ( hablun minannas, a horizontal relationship) and in fact also noticed a relationship with the natural surroundings (minannas min al-biah) all need to be considered and where the state of the endowment was discussed, whether alone or vertical dimension vertical and horizontal. ${ }^{3}$ Waqf is a religious institution in Islam which has a direct relationship functionally with efforts to solve social problems and humanity, such as poverty reduction and economic empowerment of the people. ${ }^{4}$

The definition proposed endowment Hanafi, that hold Waqif objects and giving benefits for good ${ }^{5}$ The definition proposed endowment Maliki, ${ }^{6}$ which makes the property benefits Waqif, either in the form of lease or the results to be given to those entitled to be timed according to the will Waqif. The definition proposed endowment Shafi'i school of thought,

\footnotetext{
${ }^{1}$ Student of Master Program (S2) of Notaries, Faculty of Law UNISSULA Semarang email dewifarhati85@gmail.com

${ }^{2}$ Lecturer of Faculty of Law UNISSULA

${ }^{3}$ Suhrawardi K.Lubis,dkk,2010. Wakaf \& Pemberdayaan Umat, Sinar Grafika, Jakarta, p.3

${ }^{4}$ Rozalinda, 2015 . Manajemen Wakaf Produktif, PT Raja Grafindo Persada, Jakarta, p.1

${ }^{5}$ Suhrawardi K.Lubis,dkk,2010. Wakaf \& Pemberdayaan Umat, p..4

${ }^{6}$ Ibid, p.4
} 
which hold treasures that can be taken advantage by the wholeness of the goods and the goods are lost ownership of Waqif, as utilized on something that is prohibited. ${ }^{7}$ The definition proposed endowment Hanbali, which hold the absolute freedom of property owners in running their wealth useful to treasure and decided wholeness of the entire tenure of the property, while the benefits are for the good treasure in the draw closer to God. ${ }^{8}$ While in the Quran Allah has said: QS. Al-Baqarah verse 261: "parable (income incurred by those who spend their wealth in the way of Allah) is similar to a seed that grows seven points, at each point has a hundred grains. God gives multiplied (reward) for whom He will. And Allah is the area (his gift), the Knower.

Pursuant to Article 1 paragraph 1 of Act No. 41 of 2004 on Waqf is a legal act Waqif to separate and or hand over part of their wealth to be exploited forever or for a certain period of time in accordance with their interests for purposes of worship and or the general welfare according to law. "In Article 17 Act No. 41 of 2004 on waqf stated that the waqf property to give includes movable and immovable owned and controlled by Waqif legally. The object is not moving to in waqf according to Government Regulation No. 42 of 2006 on the implementation of the Act No. 41 of waqf is: 1. Ownership Right; 2. Building Right; 3. Business Utilization Right; 4. Using Right; 5. Ownership Right on Unit Flats.

According to Islamic law of waqf has happened instantly with Waqif statement that a final offer, because the waqf agreement is seen as a unilateral legal act. But on the positive law of waqf implementation should be done with a pledge made before the Endowment Agreement Official Pledge (PPAIW) with two witnesses and should be made in the form of an agreement of Pledge of Endowments pursuant to Article 17 of Act No. 41 of 2004 on Waqf: 1. Waqf Statement conducted by Waqif to nadzir before PPAIW to be implemented by two witness; 2 . Endowments Statement referred to in paragraph (1) shall be declared orally and / or in writing and set forth in the agreement of pledge endowments by PPAIW. Preparation of Agreement of Pledge Waqf has great significance, because the Agreement of Pledge made Waqf, then waqf will be proven to be authentic in the agreement that would be able to protect and guarantee the continuity, sustainability and permanence of endowments existence itself, which can be used in a variety of issues. But in reality they have implementation of waqf is done only with the under hand as happened in KUA Wonosalam of Demak.

According to Article 1 paragraph 2 of Act No. 41 of 2004, is the party Waqif his property include: 1) Individual; according to Article 8 paragraph (1) of Act No. 41 of 2004, Waqif individual can only do endowments if requirements are met: a.Adult; b. Sensible; c. Unobstructed take legal actions; d. Valid Owner of waqf property; e. Legal Organization.

\section{Research Methods}

The research method used in this research is empirical juridical approach which in other words is a kind of sociological and legal research can be named after the field research, including reviewing the applicable law and what happens in reality in society. ${ }^{9}$ Or in other words, is a study of the actual state or the real situation that occurs in people with a view to identify and find the facts and data required, after the required data collected then leads to the identification of problems that ultimately led to the completion of the problem, ${ }^{10}$ Specifications research used in this research is descriptive analysis, which is an explanatory (explain) or depict the legislation in force associated with legal theories and practice of positive law that occurred in the community in regards to the Overview Law Against

\footnotetext{
${ }^{7}$ Ibid, p.5

${ }^{8}$ Ibid, p.6

9 Bambang Waluyo, Penelitian Hukum Dalam Praktek, (Jakarta, Sinar Grafika, 2002, p.15

${ }^{10}$ Ibid, p.16
} 
Implementation Waqf Land Rights Counsel made related to the Waqf in Under Hands Case Studies in KUA Wonosalam, Demak can support in connection with the discussion of the problem.

\section{Results And Discussion}

\subsection{Endowments Legal Force Authorization Under Hand}

In terms of whether the power Waqif under the hand can be run then the answer is they can, refer to the waqf process conducted at the District Office of Religious Affairs Wonosalam Demak No. 01 / Kua.11.21.14 / BA.00 / 01/2017 on January 11 in 2017, the process of land waqf owned represented by Abdul Latif as a Waqif to make the Pledge of Waqf.

In the process of empowerment, is attached to the consent of the heirs of referring to brother Abdul Latif as Waqif, attachment is done without any power of attorney does not use the stamp duty and notary services.

Heir own is the person or persons entitled to receive inheritance (inheritance) of people who have died, either as related by blood or by marriage, as evidenced by a certificate of inheritance. After the testator dies, the legacy assets such as land and houses turning over ownership to heirs usually consists of more than one person.

Heir statement was a letter containing information about when someone dies and anyone heirs. To obtain the strength of the evidence that is more robust, certificate of inheritance is usually witnessed by two witnesses who signed the letter. Heir statement was also made under the hand and Notary.

\subsection{Weakness And Powerful Solution Waqif Under Hand Statutory}

\subsubsection{The Weakness of Waqif Authorization The Under Hand Letter}

Article 1876 of the Civil Code describes "the one faced with a writing under the hand of the person who filed a lawsuit against him, shall admit or deny his signature explicitly, but for the heirs or people who have the right of it, suffice it they explained that they did not recognize the handwriting or signature as handwriting or signature that they represent ". Denial of a letter under the hand justified by the rules set, so if one of the heirs deny the authorization Waqiffeared there was a dispute in the future.

Article 1877 of the Civil Code explains: "If someone deny writing or signature, or if the heirs or the person who gets the right thereof can not admit it, then the judge should be ordered so that the truth of writing or signature in it examined in court".

\subsubsection{Solution Waqif Authorization The Under Hand Letter}

- Legalization

Article 15 paragraph (2) letter A of Notary Law explained that "authorities certify the signatures and establish certainty the date of the letter under the hand, by enrolling in a special book."

- Waarmeerking

In Article 15 (2) b of Law Notary Notaries explained that "authorities also posted the letter under the hand by enrolling in a special book. The book specifically referred to the book Under the Registration Letter Hand In everyday life, this authority also known as Registration of a note under the hand-coded "Register" orwaarmerking or Waarmerk.

\subsection{Concept Of Authority Under Hand To Meet The Elements Of Legal Provisions (Justice, Security, expediency)}

Justice is derived from the fair by WJS Poerwodarminto fair word means not partial, should 
not be arbitrary and impartial. Plato's justice division is composed of several things;

- Moral justice, that an act can be said to be morally unjust if it has been able to provide a balanced manner between rights and obligations.

- Procedural fairness, that if someone has been able to carry out the acts fair based procedures have been applied. ${ }^{11}$

Fairness in granting authorization under the hand Waqif shown by the appointment of one of the beneficiaries to be Waqif in waqf administration. This is done because not all heirs could be Waqif. Only one heir who could deputize be Waqif to make the Pledge of Waqf.

- Certainty Legal certainty is a question that can only be answered normatively, not sociological. Normative legal certainty when a rule is made and enacted exactly as set out clear and logical.

Certainty in the process of authorization waqif are regulations that must followed by several heirs to the waqf process.

- Expediency Legal expediency should be because everyone expects their benefits in the implementation of law enforcement. Do not let the law enforcement lead to social unrest. Because when we speak of law, we accepted only the rules alone.

In the process of this waqf benefit is obtained from the donated land contests Useful for people. Because it is basically the benefits of endowments for the benefit of the entire of the people.

\section{Closing}

\subsection{Conclusion}

- It can be concluded that the certificate authority under the hands Waqif can run as long as their witnesses from several parties. During the relevant parties agree to the provision of the administration of waqf endowments Waqif authorized to nadzir have a valid legal provisions. legally positive endowments implementation should be done with a pledge made before the Endowment Agreement Official Pledge (PPAIW) with two witnesses and should be made in the form of an agreement of Pledge of Endowments pursuant to Article 17 of Act No. 41 of 2004 on Waqf

- The weakness of the underground power in their hands under the refused letter. Refused justified by the rules set, so if one of the heirs deny the authorization Waqif feared event of a dispute later. And in order to avoid denial of the solution is to legalization or warmeerking.

- The element of fairness, predictability, and effectiveness required in the process so that the process of granting Waqif endowment granted to the laws and heir. The endowment and benefit beneficial for the entire community.

\subsection{Suggestion}

Waqf entity should provide a referral to the Waqif to register it before a notary when will provide endowments to avoid disputes in the recording process endowments.

\section{References}

[1] Bambang Waluyo, Penelitian Hukum Dalam Praktek, (Jakarta, Sinar Grafika, 2002)

[2] Rozalinda, 2015 . Manajemen Wakaf Produktif, PT Raja Grafindo Persada, Jakarta.

[3] Suhrawardi K.Lubis,dkk,2010. Wakaf \& Pemberdayaan Umat, Sinar Grafika, Jakarta.

[4] http://artonang.blogspot.com/2016/08/pengertian-keadilan.html accessed on 10 August 2018

\footnotetext{
${ }^{11}$ http://artonang.blogspot.com/2016/08/pengertian-keadilan.html accessed on 10 August 2018
} 